\title{
STRUKTUR, BENTUK, DAN ISI PERIBAHASA BAHASA KUTAI
}

\section{STRUCTURES, FORMS, AND CONTENTS OF KUTAI PROVERBS}

\author{
Suindah Sari \\ Kantor Bahasa Kalimantan Timur \\ Jalan Batu Cermin 25 Sempaja Utara, Samarinda \\ Pos-el: suindah.sari@gmail.com
}

*) Naskah diterima: 11 November 2019; direvisi: 15 November 2019; disetujui: 22 Mei 2020

\begin{abstract}
Abstrak
Penelitian ini bertujuan untuk mendeskripsikan struktur, bentuk, dan isi peribahasa bahasa Kutai. Masalah penelitian yang dikaji dalam penelitian ini, yaitu (1) struktur peribahasa bahasa Kutai, (2) bentuk peribahasa bahasa Kutai, dan (3) isi peribahasa bahasa Kutai. Untuk memecahkan masalah tersebut digunakan metode penelitian kualitatif yang bersifat deskriptif. Hasil penelitian menunjukkan bahwa peribahasa bahasa Kutai berstruktur frasa (frasa nomina, frasa verba, dan frasa adjektiva), klausa (klausa verbal dan klausa adjektival), dan kalimat (kalimat tunggal, kalimat majemuk setara, dan kalimat majemuk bertingkat). Peribahasa bahasa Kutai berdasarkan bentuknya terdiri atas ungkapan, pepatah/bidal, pemeo/semboyan, dan perumpamaan. Berdasarkan isinya, peribahasa bahasa Kutai berisi sifat/tindakan baik, sifat/tindakan buruk, nasihat, peringatan, dan sindiran.
\end{abstract}

Kata kunci: peribahasa, bahasa Kutai, struktur, bentuk, isi

\begin{abstract}
The purpose of this research is to describe structures, forms, and contents of Kutai proverbs. The research discusses about 1) the structure of Kutai proverbs, (2) forms of Kutai proverbs, and (3) contents of Kutai proverbs. It is qualitative and descriptive as well. The results show that Kutai proverbs contain of phrases (noun phrases, verb phrases, and adjective phrases), clauses (verbal clauses and adjective clauses), and sentences (single sentences, equivalent compound sentences, and multilevel compound sentences). Kutai proverbs based on its form consist of idioms, proverbs, motto, and parables. According to its contents, Kutai proverbs contain good deeds, bad deeds, advises, warnings, and satires.
\end{abstract}

Keywords: proverbs, Kutai language, structure, form, content

\section{PENDAHULUAN}

Komunikasi merupakan sesuatu yang penting dalam kehidupan manusia. Ketika berkomunikasi, manusia membangun suatu hubungan dengan sesamanya dalam suatu interaksi sosial. Manusia dalam interaksi sosial ini mencoba menunjukkan diri, pikiran, dan rasa terhadap sesama dan alam sekitarnya. Hal ini merupakan sifat dasar alamiah dan bukti bahwa manusia adalah makhluk sosial yang tidak bisa hidup tanpa manusia yang lain.

Manusia sebagai makhluk sosial menggunakan bahasa sebagai sarana untuk berinteraksi dengan sesamanya. Dalam interaksi tersebut terciptalah peribahasa. Peri- 
bahasa merupakan alat pengungkap pikiran dan perasaan yang digunakan oleh masyarakat. Peribahasa banyak menggunakan kata kiasan untuk menyampaikan suatu maksud yang berkenaan dengan orang yang dituju agar orang tersebut tidak merasa secara langsung. Peribahasa menggambarkan pandangan masyarakat, pengalaman hidup, serta corak kehidupan masyarakat secara keseluruhan.

Peribahasa dalam bahasa memegang peranan penting dalam berkomunikasi. Dengan peribahasa, penggunaan bahasa dalam berkomunikasi, baik lisan maupun tulisan akan lebih menarik dan menguatkan makna.

Ada berbagai macam peribahasa pada berbagai bahasa daerah yang ada di Indonesia. Salah satu peribahasa berbahasa daerah yang ada di Indonesia adalah peribahasa bahasa Kutai. Bahasa Kutai merupakan satu di antara bahasa daerah yang masih hidup dan berkembang di Kabupaten Kutai Kartanegara, Kabupaten Kutai Timur, dan Kabupaten Kutai Barat. Tiga kabupaten ini menjadi tempat yang memiliki penutur bahasa Kutai yang paling dominan. Bahasa Kutai ada dan berkembang di Kalimantan Timur, terutama di wilayah bekas Kerajaan Kutai Kartanegara (Darma, dkk, 2013:v).

Bahasa Kutai memiliki peribahasa yang cukup banyak. Keberadaan peribahasa ini perlu disebarluaskan untuk memperkaya bahasa Nasional. Kantor Bahasa Kalimantan Timur, sebagai lembaga yang menangani masalah kebahasaan dan kesastraan di wilayah Kalimantan Timur, telah melakukan penelitian tentang peribahasa bahasa Kutai dalam 'Peribahasa Bahasa Daerah di Kalimantan Timur' oleh Nurhayati, dkk. (2009). Penelitian ini menemukan, mendeskripsikan, dan menganalisis peribahasa bahasa Kutai dari segi nilai budaya.
Penelitian tentang peribahasa bahasa Kutai dilihat dari segi struktur, bentuk, dan isinya belum pernah dilakukan. Untuk itu, diperlukan penelitian dan pendokumentasian tentang peribahasa bahasa Kutai khususnya dari segi struktur, bentuk, dan isinya. Hal ini akan sangat bermanfaat untuk studi kebahasaan dan pengajaran bahasa Kutai, khususnya tentang struktur, bentuk, dan isi peribahasa bahasa Kutai.

Penelitian tentang peribahasa bahasa daerah di Indonesia yang pernah dilakukan dan menjadi bahan acuan serta pertimbangan dalam penelitian ini, yaitu sebagai berikut. Pertama, Ponulele, dkk. (1998) dalam Ungkapan dan Peribahasa Bahasa Kaili yang membahas struktur serta makna ungkapan dan peribahasa Bahasa Kaili. Kedua, Rambitan dan Mandolang (2014) dalam Ungkapan dan Peribahasa Bahasa Mongondow yang membahas tentang struktur, fungsi, serta nilai ungkapan dan peribahasa bahasa Mongondow. Ketiga, Yaser dan Efendi (2018) dalam Ungkapan Bahasa Kaili Dialek Rai di Kecamatan Sirenja Kabupaten Donggala.

Berdasarkan latar belakang yang telah diuraikan tersebut, masalah dalam penelitian ini dirumuskan sebagai berikut. Pertama, bagaimana struktur peribahasa bahasa Kutai? Kedua, bagaimana bentuk peribahasa bahasa Kutai? Ketiga, apa isi peribahasa bahasa Kutai?

Penelitian tentang struktur, bentuk, dan isi peribahasa bahasa Kutai memiliki dua tujuan, yaitu tujuan teoretis dan tujuan praktis. Tujuan teoretis dari penelitian ini adalah (1) mendeskripsikan struktur peribahasa bahasa Kutai; (2) mendeskripsikan bentuk peribahasa bahasa Kutai; dan 3) mendeskripsikan isi peribahasa bahasa Kutai. Tujuan praktis dari penelitian ini adalah menambah khazanah pengetahuan tentang ilmu bahasa daerah Nusantara, khususnya peribahasa bahasa Kutai. 


\section{LANDASAN TEORI}

Penelitian ini tidak membedakan antara peribahasa dan ungkapan, akan tetapi memasukkan ungkapan ke dalam peribahasa. Hal ini seturut dengan pengertian peribahasa menurut KBBI yaitu kelompok kata atau kalimat yang tetap susunannya, biasanya mengiaskan maksud tertentu (dalam peribahasa termasuk juga bidal, ungkapan, perumpamaan); ungkapan atau kalimat ringkas padat, berisi perbandingan, perumpamaan, nasihat, prinsip hidup atau aturan tingkah laku. Peribahasa dapat berstruktur frasa, klausa, kalimat tunggal, maupun kalimat majemuk.

Peribahasa dilihat dari bentuknya, terdiri dari empat jenis, yaitu ungkapan, pepatah/bidal, perumpamaan, dan pemeo/ semboyan.

a. Ungkapan

Chaer, dkk. dalam Yaser dan Efendi (2018) mengemukakan bahwa ungkapan merupakan segala sesuatu yang diungkapkan dalam wujud gabungan kata dan maknanya tidak sama dengan pemaduan makna setiap kata yang membentuk ungkapan itu. Sedangkan menurut Kridalaksana (2008:90), ungkapan adalah konstruksi yang maknanya tidak sama dengan gabungan makna anggotaanggotanya. Dari kedua definisi tersebut dapat disimpulkan bahwa ungkapan adalah gabungan kata yang maknanya berbeda dari kata-kata yang membentuknya.

b. Pepatah/bidal

Pepatah/bidal menurut Badudu (dalam Ponulele, 1998:14) adalah peribahasa yang mengandung nasihat atau ajaran dari orang tua-tua (biasanya dipakai atau diucapkan untuk mematahkan lawan bicara. Hakim (dalam Rambitan dan Mandolang, 2014) mengemukakan bahwa pepatah berfungsi untuk mem- berikan nasihat dan petuah-petuah, yaitu ajaran-ajaran tua-tua.

c. Perumpamaan

Perumpamaan ialah kalimat yang mengungkapkan keadaan atau kelakuan seseorang dengan mengambil perbandingan (Badudu dalam Ponulele, 1998: 16). Sedangkan menurut Waridah (dalam Adhani, 2016), perumpamaan adalah peribahasa yang berisi perbandingan yang ditandai dengan penggunaan kata-kata yang bermakna membandingkan di antaranya bak, seperti, bagaikan, laksana, dan seumpama. Dari kedua definisi tersebut dapat disimpulkan bahwa perumpamaan adalah peribahasa yang berisi perbandingan tentang keadaan atau kelakuan seseorang dengan suatu hal menggunakan katakata yang bermakna membandingkan.

d. Pemeo/semboyan

Pemeo/semboyan menurut Kridalaksana (2008:178) adalah semboyan yang terjadi dari peribahasa; peribahasa yang dijadikan semboyan. Sedangkan menurut Ratna (dalam Adhani, 2016) pemeo/ semboyan adalah peribahasa yang dijadikan semboyan atau moto.

\section{METODE PENELITIAN}

Penelitian ini merupakan penelitian kualitatif. Penelitian kualitatif atau metodologi kualitatif menurut Bogdan dan Taylor (dalam Moleong, 2018:4) merupakan prosedur penelitian yang menghasilkan data deskriptif berupa kata-kata tertulis atau lisan dari orang-orang dan perilaku yang dapat diamati. Metode yang digunakan dalam penelitian ini adalah metode deskriptif, yaitu mengkaji peribahasa bahasa Kutai dari segi struktur, bentuk, dan isinya. Sumber data dalam penelitian ini berasal dari sumber tulis, yaitu Kamus Bahasa Kutai-Bahasa Indonesia yang disusun oleh Darma, dkk. (2007) dan laporan pene- 
litian Peribahasa Bahasa Daerah di Kalimantan Timur oleh Nurhayati, dkk. (2013).

Penelitian ini dilakukan berdasarkan tiga tahap, yaitu tahap penyediaan data, tahap analisis data, dan tahap penyajian analisis data (Sudaryanto, 1986:57). Penelitian ini menggunakan metode pengumpulan data melalui dokumen. Teknik pengumpulan data yang dilakukan dalam penelitian ini menggunakan teknik catat. Pencatatan dilakukan terhadap peribahasa yang terdapat dalam kedua buku tersebut dengan cara memindahkan data yang sesuai dengan variabel yang akan diteliti ke dalam kartu data. Pencatatan dilakukan pada kartu data dilanjutkan dengan analisis data.

Teknik analisis data yang digunakan dalam penelitian ini adalah teknik analisis deskriptif. Langkah-langkah untuk menganalisis data, yaitu mengatur atau mengurutkan data yang sudah dikumpulkan, mengklasifikasikan data berdasarkan kategori atau kriterianya, dan melakukan analisis data lalu mendeskripsikannya dengan jelas.

\section{HASIL DAN PEMBAHASAN}

Pada bagian hasil dan pembahasan ini diuraikan bagaimana struktur, bentuk, dan isi peribahasa bahasa Kutai.

\section{Struktur Peribahasa Bahasa Kutai}

Struktur peribahasa bahasa Kutai terdiri atas frasa, klausa, dan kalimat.

\section{Frasa}

Frasa menurut Kentjono (dalam Indrawati, dkk., 2007:14) adalah satuan gramatik yang terdiri dari dua atau lebih kata yang tidak berciri klausa dan pada umumnya menjadi pembentuk klausa. Peribahasa bahasa Kutai yang berstuktur frasa hanya ditemukan pada peribahasa yang berbentuk ungkapan saja. Peribahasa bahasa Kutai antara lain berstruktur frasa nomina, frasa verba, dan frasa adjektiva.

a. Frasa nomina

Frasa nomina menurut Ramlan (1996: 158) adalah frasa yang memiliki distribusi yang sama dengan kata nomina. Perhatikan kedua peribahasa bahasa Kutai yang berstruktur frasa nomina berikut.

(1) bunga tanyung

'bunga tanjung'

(2) bukku ruas

'buku (dan) ruas'

Frasa (1) bermakna seorang gadis yang menantikan kedatangan pujaan hatinya. Ia sering datang ke tanjung sehingga ia digelari bunga tanjung. Frasa (1) memiliki unsur inti yaitu bunga dan unsur atribut yaitu tanyung. Frasa (2) memiliki dua unsur inti yaitu bukku dan ruas. Kedua frasa tersebut dapat menduduki distribusi yang sama dengan nomina. b. Frasa verba

Frasa verba adalah satuan bahasa yang terbentuk dari dua kata atau lebih dengan verba sebagai intinya tetapi bentuk ini tidak merupakan klausa (Alwi, dkk., 2010:162). Perhatikan contoh peribahasa bahasa Kutai berikut.

(3) ngalak hati

'mengambil hati'

(4) tattak rebus

'potong (dan) rebus'

Kedua peribahasa tersebut berstruktur frasa verba. Unsur inti pada frasa (3) adalah ngalak, sedangkan hati merupakan unsur atribut. Frasa (4) memiliki dua unsur inti, yaitu tattak dan rebus.

c. Frasa adjektiva

Frasa adjektiva diberi batasan sebagai frasa yang memiliki distribusi yang sama dengan adjektiva dan berfungsi sebagai keterangan nomina (Masfufah, 2009:171). 
Perhatikan contoh peribahasa bahasa Kutai berikut.

(5) burruk sikku

'buruk sikut'

(6) muta tuli

'buta tuli'

Kedua peribahasa tersebut berstruktur frasa adjektiva. Frasa (5) memiliki unsur inti yaitu burruk, sedangkan sikku merupakan unsur atribut. Frasa (6) memiliki dua unsur inti, yaitu muta dan tuli. Kedua frasa tersebut memiliki distribusi yang sama dengan adjektiva dan dapat berfungsi sebagai keterangan nomina dalam suatu kalimat.

\section{Klausa}

Klausa menurut Chaer (2015:41) merupakan satuan sintaksis yang berada di atas satuan frasa dan di bawah satuan kalimat, berupa runtunan kata-kata bekonstruksi predikatif. Berdasarkan kategori yang mengisi fungsi $\mathrm{P}$, klausa pada peribahasa bahasa Kutai terdiri dari klausa verbal dan klausa adjektival.

a. Klausa verbal

Klausa verbal adalah klausa yang predikatnya berkategori verba atau frasa verbal (Khairah, 2014:117). Perhatikan contoh peribahasa bahasa Kutai berikut.

(7) muttik kambeng

'memetik bunga'

(8) ncarang empat mata

'berbicara empat mata'

(9) kesambeh rangges

'binatang congcorang meranggas'

Ketiga peribahasa tersebut berstruktur klausa verbal. Pengisi unsur P pada contoh (7) adalah muttik yang diikuti oleh unsur $\mathrm{O}$, yaitu kambeng. Pengisi unsur P pada contoh (8) adalah ncarang yang diikuti oleh unsur $\mathrm{K}$, yaitu empat mata. Adapun pengisi unsur $P$ pada contoh (9) adalah rangges yang diawali oleh unsur S, yaitu kesambeh. Secara semantik, klausa pada peribahasa-peribahasa tersebut dapat dibedakan menjadi beberapa jenis. Klausa pada peribahasa (7) dan (8) merupakan klausa verbal tindakan, sedangkan klausa pada peribahasa (9) merupakan klausa verbal keadaan.

b. Klausa adjektival

Klausa adjektival adalah klausa yang predikatnya berupa adjektiva atau frasa adjektiva (Khairah, 2014:123). Perhatikan contoh peribahasa bahasa Kutai berikut.

(10) sanggar kanynyer

'pisang goreng keras'

Peribahasa (10) berstruktur klausa adjektival. Klausa tersebut terdiri dari unsur $S$ yang diisi oleh kata sanggar dan P yang diisi oleh kata kanynyer. Kata kanynyer sebagai pengisi unsur P pada klausa tersebut merupakan kata sifat/adjektiva.

\section{Kalimat}

Kalimat menurut Alwi, dkk (2003:311) adalah satuan bahasa terkecil, dalam wujud lisan atau tulisan, yang mengungkapkan pikiran yang utuh. Setiap satuan kalimat dibatasi oleh adanya jeda panjang yang disertai nada akhir turun atau naik (Ramlan, 1996:25). Peribahasa bahasa Kutai yang berbentuk kalimat antara lain berstruktur kalimat tunggal, kalimat majemuk setara, dan kalimat majemuk bertingkat.

a. Kalimat tunggal

Kalimat tunggal menurut Keraf (dalam Masfufah, 2009:333) adalah kalimat yang hanya mengandung satu pola kalimat dan perluasannya tidak membentuk pola kalimat yang baru. Perhatikan peribahasaperibahasa bahasa Kutai berikut.

(11)Rammok-remes harta disayangi ge.

'Hancur/tidak berguna harta disayangi juga.' 
(12)Bebek ngulangi carren.

'Bebek mendatangi comberan.'

(13) Tegak buaya mulang ke liang.

'Seperti buaya pulang ke sarang.'

Ketiga kalimat tersebut merupakan kalimat tunggal karena terdiri dari satu klausa baik dilengkapi dengan unsur yang lain mauun tidak. Peribahasa (11) memiliki unsur $S$ yaitu rammok-remes harta dan unsur P yaitu disayangi ge. Peribahasa (12) memiliki unsur $S$ yaitu bebek, unsur $P$ yaitu ngulangi, dan unsur O yaitu carren. Adapun peribahasa (13) memiliki unsur K yaitu tegak dan ke sarang, unsur S yaitu buaya, dan unsur $P$ yaitu mulang.

b. Kalimat majemuk setara

Kalimat majemuk setara adalah kalimat majemuk yang klausa-klausa di dalamnya memiliki hubungan koordinasi. Koordinasi menggabungkan dua klausa atau lebih yang masing-masing mempunyai kedudukan yang setara dalam struktur konstituen kalimat (Alwi, dkk, 2010:396). Perhatikan peribahasa-peribahasa bahasa Kutai berikut.

(14) Tangganya disintak dan tangga urang diulur.

'Tangga milik sendiri ditarik dan tangga orang diturunkan.'

(15) Odah nyawa jadi macan, odah urang jadi belacan.

'(Di) kampung sendiri jadi macan, (di) kampung orang jadi terasi.'

Kedua peribahasa tersebut berstruktur kalimat majemuk setara. Peribahasa (14) terdiri atas dua klausa, yaitu tangganya disintak dan tangga urang diulur. Klausa pertama memiliki unsur $S$, yaitu tangganya dan unsur P yaitu disintak. Klausa kedua memiliki unsur $S$ yaitu tangga urang dan unsur P yaitu diulur. Kedua klausa tersebut digabungkan dengan konjungsi koordinatif penanda hubungan penambahan, yaitu dan.
Peribahasa (15) terdiri dari dua klausa yaitu odah nyawa jadi macan dan odah urang jadi belacan. Klausa pertama memiliki unsur K yaitu odah nyawa dan unsur $\mathrm{P}$ yaitu jadi macan. Klausa kedua memiliki unsur Kodah urang dan unsur P yaitu jadi belacan. Kedua klausa tersebut digabungkan dengan tanda baca koma (,), tanpa menggunakan konjungsi.

c. Kalimat majemuk bertingkat

Kalimat majemuk bertingkat adalah kalimat majemuk yang terdiri dari klausaklausa yang memiliki hubungan yang tidak setara/sederajat. Perhatikan peribahasaperibahasa bahasa Kutai berikut.

(16)Jangan sanggop nyembeleh manok malam amun ndik cakap mbuang tungautungaunya.

'Jangan sanggup menyembelih ayam malam hari jika tidak mampu membuang tungau-tungaunya.'

(17)Tampulu maseh rabung nyaman mluruskan amun lah nyedi parang payah mujuri.

'Selagi masih rebung mudah meluruskan kalau sudah jadi bambu susah membetulkannya.'

Kedua peribahasa tersebut berstruktur kalimat majemuk bertingkat. Antarklausa pada masing-masing peribahasa tersebut memiliki hubungan yang tidak setara. Kedua klausa tersebut digabungkan dengan konjungsi amun yang merupakan konjungsi subordinatif penanda hubungan persyaratan.

Peribahasa (16) terdiri dari dua klausa yaitu, jangan sanggop nyembeleh manok malam dan ndik cakap mbuang tungau-tungaunya. Klausa pertama memiliki unsur $\mathrm{P}$ jangan sanggop nyembeleh, unsur O yaitu manok, dan unsur K yaitu malam. Sedangkan klausa kedua memiliki unsur $\mathrm{P}$ yaitu ndik cakap mbuang dan unsur $\mathrm{O}$ yaitu tungau-tungaunya. Peribahasa (17) terdiri dari dua klausa yaitu, 
tampulu maseh rabung nyaman mluruskan dan lah nyedi parang payah mujuri. Klausa pertama memiliki unsur S yaitu tampulu maseh rabung dan unsur P yaitu nyaman mluruskan, sedangkan klausa kedua memiliki unsur $\mathrm{S}$ yaitu lah nyedi parang dan $\mathrm{P}$ yaitu payah mujuri.

\section{Bentuk Peribahasa Bahasa Kutai}

Peribahasa bahasa Kutai berdasarkan bentuknya terdiri dari empat jenis, yaitu ungkapan, pepatah, bidal/pemeo, dan perumpamaan.

\section{Ungkapan}

Ungkapan dikenal juga dengan istilah idiom yang berasal dari bahasa Belanda. Perhatikan contoh peribahasa bahasa Kutai berikut.

(18)bontok nasik

'pemalas'

(19)eretenteng

'pasangan yang selalu bersama'

(20)kereng bulu

'lembab (tidak benar-benar kering)'

Ketiga peribahasa bahasa Kutai tersebut berbentuk ungkapan. Ungkapan bahasa Kutai tidak berbeda dengan ungkapan bahasa Indonesia pada umumnya. Ungkapan bahasa Kutai terbentuk dari gabungan dua kata yang memiliki makna baru yang berbeda dari kata-kata yang membentuknya.

\section{Pepatah/bidal}

Pepatah/bidal berisi nasihat atau pengajaran dan peringatan. Perhatikan contoh peribahasa bahasa Kutai berikut.

(21)Mana jetu bueh amun nde ke bener.

'(Di) mana jatuh (nya) buah kalau tidak ke dekat pohon.'

(22)Biar genting asal jangan pegat.

'Walaupun genting asal jangan putus.'
(23)Jangan sanggop nyembeleh manok malam amun ndik cakap mbuang tungautungaunya.

‘Jangan sanggup menyembelih ayam malam hari jika tidak mampu membuang tungau-tungaunya.'

(24)Pore sabbetnya pore ge jukutnya.

'Besar gelombang besar juga ikannya.'

Pepatah bahasa Kutai yang berisi larangan antara lain ditandai dengan penggunaan kata asal jangan dan jangan. Pepatah mengandung nilai-nilai dan norma yang berlaku dalam kehidupan sehari-hari.

\section{Pemeo/semboyan}

Pemeo/semboyan adalah semboyan yang menjadi peribahasa; peribahasa yang dijadikan semboyan (Kridalaksana, 2008: 178). Perhatikan peribahasa bahasa Kutai berikut.

(25)Ade sama dimakan, nade sama nahan.

'Ada sama-sama dimakan, tidak ada sama-sama menahan.'

(26) Lai durian, sapa lalai ketinggalan.

'Buah lai buah durian, siapa lalai ketinggalan.'

(27) Jahat pulut binasa pandan, jahat sungut binasa badan.

‘Jelek beras ketan rusak pandan, jelek mulut rusak badan.'

Ketiga peribahasa tersebut berbentuk pemeo/semboyan. Pemeo/semboyan bahasa Kutai dapat berbentuk seperti karmina, yaitu pantun singkat yang terdiri dari satu baris lampiran dan satu baris isi. Karmina tersebut dirapatkan menjadi satu baris seperti pada peribahasa (26) dan (27).

\section{Perumpamaan}

Perumpamaan menurut Sudaryat (dalam Yaser dan Efendi, 2018) adalah peribahasa yang berisi perbandingan dari ke- 
hidupan manusia. Perumpamaan bahasa Kutai antara lain sebagai berikut.

(28) Taggek kapak nyallami bliung.

'Seperti kapak menyelami beliung.'

(29) Tegak kapok ditimpu angin.

'Seperti kapuk ditimpu angin.'

(30) Suaranya tegak kumbang dalam buluh.

'Suaranya seperti kumbang dalam buluh.'

(31)Ngambung jela tapi maseh nyewati pelumpungan.

'Melambungkan jala tetapi masih memegangi sambungan antara jala dan tali.'

Perumpamaan bahasa Kutai dapat ditandai dengan penggunaan kata taggek dan tegak yang bermakna seperti. Kata taggek dan tegak dapat diletakkan di awal maupun setelah kata yang ingin diperbandingkan dengan suatu hal/keadaan. Perumpamaan bahasa Kutai bisa juga tidak menggunakan kata bermakna perumpamaan.

\section{Isi Peribahasa Bahasa Kutai}

Peribahasa bahasa Kutai antara lain berisi sifat/tindakan baik, sifat/tindakan buruk, nasihat, peringatan, dan sindiran.

\section{Sifat/tindakan baik}

Peribahasa bahasa Kutai yang berbentuk ungkapan antara lain berisi tentang sifat/ tindakan baik dan sifat/tindakan buruk. Peribahasa bahasa Kutai yang berisi tentang sifat/tindakan baik antara lain sebagai berikut.

(32) mujjur arus

'membujur arus'

(33) ngalak hati

'mengambil hati'

(34) tangkap lappas

'tangkap lepas'
Peribahasa-peribahasa tersebut berisi tentang sifat/tindakan baik. Mujjur arus merupakan sifat orang yang sangat jujur dalam melakukan suatu perbuatan, tingkah laku, dan perkataan seperti halnya lurusnya arus sungai. Ngalak hati merupakan suatu sifat orang yang mudah dalam menjalin pertemanan dengan orang lain karena mampu menyenangkan hati orang supaya disayangi dan sebagainya. Tangkap lappas merupakan sifat orang yang senang bekerja dan tidak memilih jenis pekerjaan. Apabila pekerjaan yang satu telah selesai maka dia akan mencari pekerjaan yang lain.

\section{Sifat/tindakan buruk}

Peribahasa bahasa Kutai yang berisi tentang sifat/tindakan buruk antara lain sebagai berikut.

(35)otak tompol

'otak tumpul'

(36)burruk sikku

'buruk sikut'

(37)perumpung tunu

'sejenis bambu dibakar'

Peribahasa-peribahasa tersebut berisi tentang sifat/tindakan buruk. Otak tompol merupakan sifat orang yang lamban dalam berpikir. Burruk sikku merupakan sifat seseorang yang meminta kembali barang yang telah diberikan pada orang lain. Perumpung tunu merupakan sifat seseorang yang berbicara cepat dan meledak-ledak.

\section{Nasihat}

Peribahasa bahasa Kutai yang berisi nasihat antara lain sebagai berikut.

(38)Pantak paku di papan.

'Tancap paku di papan.'

(39)Lalat ngiringi tombong

'Lalat mengiringi koreng.' 
(40)Jahat pulut binasa pandan, jahat sungut binasa badan.

'Jelek beras ketan rusak daun pandan, jahat mulut rusak badan.'

Peribahasa-peribahasa tersebut berisi nasihat. Peribahasa (38) mengajarkan untuk bersikap tegar dan konsisten seperti paku yang ditancapkan di papan yang tidak mudah dicabut. Peribahasa (39) mengajarkan untuk mandiri/ bisa melepaskan diri dari ketergantungan. Peribahasa (40) mengajarkan untuk menjaga tutur kata karena kesalahan tutur kata bisa mengakibatkan suatu hal yang fatal.

\section{Peringatan}

Perhatikan peribahasa-peribahasa bahasa Kutai berikut.

(41)Hendak nurut gajah, pelandok carek burit.

'Hendak meniru gajah, kancil merobek pantat.'

(42)Panasnya tegak api serumpun.

'Panasnya seperti api serumpun.'

(43)Sudah bengkok sandar ke timpang.

'Sudah bengkok bersandar ke timpang.'

Peribahasa-peribahasa tersebut berisi peringatan. Peribahasa (41) berisi tentang peringatan untuk tidak menginginkan sesuatu dan meniru apa yang didapat orang lain tanpa melihat kemampuan diri sendiri karena akan membuat diri sendiri sakit dan menderita. Peribahasa (42) berisi peringatan untuk tidak menyulut kemarahan suatu kelompok karena bisa menyebabkan permusuhan dan pertikaian antarkelompok. Peribahasa (43) berisi peringatan untuk tidak membebani orang lain dengan suatu hal tanpa melihat kemampuan orang tersebut terlebih dahulu.

\section{Sindiran}

Perhatikan peribahasa-peribahasa bahasa Kutai berikut.
(44)Mbentang pinang kali carangnya.

'Batang pinang sekali bicaranya.'

(45)Diberi bahu ndak kepala.

'Diberi bahu hendak kepala.'

(46)Dah terumpak baru tahukan bincul.

'Sudah terbentur baru tahukan benjol.'

Ketiga peribahasa tersebut berisi sindiran. Peribahasa (44) berisi sindiran kepada seseorang yang berbicara secara datar (seperti batang pinang) tanpa intonasi yang mendukung sehingga perasaan dan pesan yang ingin disampaikan sulit ditangkap. Peribahasa (45) berisi sindiran kepada seseorang yang masih saja menginginkan lebih setelah mendapatkan suatu hal/benda secara tidak wajar dengan menghalalkan segala macam cara. Peribahasa (46) berisi sindiran kepada seseorang yang sering lupa pada kelemahan diri saat dalam posisi nyaman.

\section{PENUTUP}

Peribahasa bahasa Kutai berdasarkan strukturya terdiri dari frasa, klausa, dan kalimat. Peribahasa bahasa Kutai yang berstruktur frasa terdiri dari tiga jenis yaitu frasa nomina, frasa verba, dan frasa adjektiva. Peribahasa bahasa Kutai yang berstruktur klausa terdiri dari dua jenis, yaitu klausa verbal dan klausa adjektiva. Adapun peribahasa bahasa Kutai yang berstruktur kalimat terdiri atas tiga jenis, yaitu kalimat tunggal, kalimat majemuk setara, dan kalimat majemuk bertingkat.

Peribahasa bahasa Kutai berdasarkan bentuknya terdiri atas empat jenis, yaitu ungkapan, pepatah/bidal, pemeo/semboyan, dan perumpamaan. Berdasarkan isinya, peribahasa bahasa Kutai terdiri atas lima jenis yaitu sifat/tindakan baik, sifat/tindakan buruk, nasihat, peringatan, dan sindiran. 


\section{DAFTAR PUSTAKA}

Adhani, Agnes. 2016. Peribahasa, Maknanya, dan Sumbangannya Terhadap Pendidikan Karakter. Jurnal Magistra Edisi XXVIII No 97: 97"110. Madiun: Universitas Widya Mandala.

Chaer, Abdul. 2015. Sintaksis Bahasa Indonesia. Jakarta: Rineka Cipta.

Darma, M. Erwin, dkk. 2013. Kamus Bahasa Kutai-Bahasa Indonesia. Samarinda: Kantor Bahasa Kalimantan Timur.

Indrawati, dkk. 2007. Sintaksis Bahasa Kutai. Samarinda: Kantor Bahasa Kalimantan Timur.

Khairah, Miftahul dan Sakura Ridwan. 2014. Sintaksis: Memahami Satuan Kalimat Perspektif Fungsi. Jakarta: Bumi Aksara.

Kridalaksana, Harimurti. 2009. Kamus Linguistik. Jakarta: Gramedia Pustaka Utama.

Masfufah, Nurul, dkk. 2009. Tata Bahasa Kutai. Samarinda: Kantor Bahasa Kalimantan Timur.

Moeleong, Lexy J. 2018. Metodologi Penelitian Kualitatif. Bandung: Remaja Rosdakarya.
Nurhayati, Mira. 2009. Peribahasa Bahasa Daerah di Kalimantan Timur. Samarinda: Kantor Bahasa Kalimantan Timur.

Ponulele, dkk. 1998. Ungkapan dan Peribahasa Bahasa Kaili. Jakarta: Pusat Pembinaan dan Pengembangan Bahasa.

Rambitan, Siska dan Nova Mandolang. 2014. Ungkapan dan Peribahasa Mongondow. Jurnal LPPM Bidang Ekosusbudkum Volume 1 No 2: 71-85. Manado: Universitas Sam Ratulangi.

Ramlan. 1996. Sintaksis. Yogyakarta: Karyono.

Sudaryanto. 1986. Metode Linguistik: Bagian Pertama ke Arah Memahami Metode Linguistik. Yogyakarta: Gadjah Mada University Press.

Yaser, Umi dan Efendi. 2018. Ungkapan Bahasa Kaili Dialek Rai di Kecamatan Sirenja Kabupaten Donggala. Dalam http:// jurnal.untad.ac.id/jurnal/index. php/ BDS/article/view/9953/7914 diakses tanggal 3 Oktober 2019. 